\title{
Stock Market Investors' Guide to Corporate Dividend Policy: Evidence from Pharmaceuticals and Chemicals Industries in Bangladesh
}

\author{
Tanbir Ahmed Chowdhury \\ Dept. of Business Administration, East West University \\ A/2, Jahurul Islam City Gate, Aftab Nagar Main Rd, Dhaka-1212, Bangladesh \\ Tel: 88-017-4842-7741_E-mail: tanbir@ewubd.edu \\ Jannatunnesa (Corresponding author) \\ Dept. of Business Administration, East West University \\ A/2, Jahurul Islam City Gate, Aftab Nagar Main Rd, Dhaka-1212, Bangladesh \\ Tel: 88-017-1110-7944Ｅ-mail: moniducb168@yahoo.com
}

Received: March 2, 2017 Accepted: March 25, $2017 \quad$ Published: June 1, 2017

doi:10.5296/ajfa.v9i1.10871 URL: https://doi.org/10.5296/ajfa.v9i1.10871

\begin{abstract}
Dividend policy has been an important component in the arena of financial literature and providing evidence that dividend payout decisions are affected by various factors. Numerous studies have been conducted so far on corporate dividend policy in Bangladesh. The pharmaceuticals and chemicals industries of Bangladesh offer a lot of investment panorama for the retail investors. This research has been an endeavor to determine the factors affecting the dividend policy of these promising industries, and guide the investment decisions of the equity investors. In this attempt, this study is also a unique one to incorporate the chemicals industry along with the pharmaceuticals industry as both the industries constitute the 'pharmaceuticals and chemicals sector' listed in the stock market of Bangladesh. The study is a quantitative one based on secondary data. It comprises of different statistical analyses such as descriptive statistics, correlation matrix and multiple linear regression analysis, etc. Firm size, growth, liquidity, profitability, last year's dividend and $\mathrm{P} / \mathrm{E}$ ratio are used as dependent variables. Besides, ownership structure, firm age, market share, and risk are used as control variables. The study explores that firm size has significant negative and last year's dividend
\end{abstract}


has significant positive relationship with dividend payout. However, dividend payout does not depend on firm growth, liquidity, profitability and $\mathrm{P} / \mathrm{E}$ ratio of a firm. The research outcome may have important implications for the improvement of investors' perceptions, which may assist them in their investment decisions in the researched industries. Certainly more work lies ahead to add to explanations for why some of the factors affect the dividend policy of the industries, while others have no significant impact thereon.

Keywords: Dividend Policy, Multiple Regression Analysis, Pharmaceuticals and Chemicals Industries, Investors 


\section{Introduction}

Dividend policy has been an important component in the arena of financial literature and providing evidence that dividend payout decisions are affected by various factors. The pharmaceuticals and chemicals industries of Bangladesh offer a lot of investment panorama in the stock market, especially for the retail investors. This research has been an endeavor to determine the factors affecting the dividend policy of these promising industries of the country.

The relevance and irrelevance of dividend policy have been analyzed by finance scholars based on a number of dividend policy theories (Miller and Modigliani, 1961; Gordon, 1956; Linter, 1959). However, studies revealed that investors expect firms to be fairly valued irrespective of the dividend policies followed by the firms. Current dividend decreases the shareholders' uncertainty, which contributes to the company's higher stock value and in turn higher value of the firm (Gitman, 2009). Therefore, research concentrated on studies relating to dividend policy and the value of the firm as well as the wealth of shareholders (Baker and Powell, 1999; Omran \& Pointon, 2004).

Numerous studies examined the individual factors affecting dividend policy with detailed analyses and interpretations, especially in the developed globe. Nevertheless, hardly any research attempts have been taken so far in this context in Bangladesh, particularly for the stock market investors. The study intends to depict the determinants of corporate dividend policy, especially as a basic guideline for the actual and potential investors in the stock market. In this regard, this study proceeds to examine the relationship of dividend payout with a number of firm-specific factors, with explicit focus on both the pharmaceuticals and chemicals industries of Bangladesh.

The study is a quantitative one comprising of different statistical analyses. In order to construct the theoretical framework, relevant secondary data have been used from different sources such as journal articles, websites, books, etc. Besides, the dataset for the statistical analysis consists of mainly secondary data collected from the websites of DSE and annual reports of sample companies. A total of 15 companies are selected from both the pharmaceuticals and chemicals companies listed under the sector titled 'pharmaceuticals and chemicals' in Dhaka Stock Exchange (DSE), the main stock exchange of Bangladesh. A number of variables have been scrutinized based on empirical studies, and have been analyzed using basic descriptive statistics. In order to examine the relative influence of each of the factors on a firm's dividend payout, several hypotheses have been formulated and tested using correlation matrix and multiple regression analysis.

The study outcomes may offer important guidelines to the actual and prospective stock market investors, especially those interested in the pharmaceuticals and chemicals sectors of DSE. Among the other stakeholders, regulators in the capital market, corporations' management, stock dealers and brokers, etc. can also be informed of the results of the investigation and concentrate on necessary policy implications accordingly. 
The rest of the document is organized as follows. Section 2 consists of the objective of the study and research questions. Section 3 discusses the rationale for the study. Section 4 constructs the literature review. Section 5 reports the empirical methodology including sample and data collection, and statistical analyses. Section 6 illustrates the approaches to investigate a number of variables in terms of their influence on corporate dividend policy of the pharmaceuticals and chemicals industries of Bangladesh. Section 7 consists of empirical analysis comprising of a number of statistical analyses. Section 8 presents possible contributions and implications of the research outcome. Section 9 concludes. Section 10 outlines some limitations of the study as well as probable approaches to future research.

\section{Objective of the Study}

It is important to ascertain the factors that influence corporation's dividend policy, which in turn may control the equity investment decisions of individual investors. An understanding of these factors can dig up investors' notion to such an extent that brings stability in their investment. Thus, the study intended to analyze the potential determinants of dividend policy in the pharmaceuticals and chemicals industries of Bangladesh. Therefore, the research questions are:

1. What are the factors (variables) that specifically affect the dividend policy of these industries?

2. What is the relative importance of every individual determinant on the dividend payout simultaneously?

\section{Rationale for the Study}

Most of the studies conducted so far focused only on the pharmaceuticals industry, and mainly on perspectives such as performance analysis, problems and prospects of the sector, the impact of TRIPS agreement, etc. Dividend policy of an industry, however, concentrates on the determination of level of dividends for its shareholders. Thus, an understanding of the dividend policy of a particular industry bears significance for the stock market investors. Nevertheless, very few studies have been conducted on the dividend policy of corporations of Bangladesh, especially for capital market investors. This study concentrated utterly on the pharmaceuticals and chemicals industries of Bangladesh in order to identify the relative significance of some recognized factors that affect dividend policy.

This research will instill value to the existing financial literature in Bangladesh, especially in the context of corporate dividend policy. From this research, stock market investors can enlighten themselves with the understanding of the factors that should methodically influence a firm's dividend policy in the pharmaceuticals and chemicals industries in Bangladesh. Thus, the study has important implications for the improvement of investors' perceptions, which may assist them in their capital market investment decisions. The study is also expected to offer an opportunity to the respective company' management, capital market regulators, stock brokers and dealers, researches, etc. to apply the knowledge of the research findings in their respective work arena. 


\section{Literature Review}

Dividend policy decision is one of the most controversial concerns in modern corporate finance. As stated by Black (1976), "the harder we look at dividend, the more it seems like a puzzle with pieces that just don't fit together." According to Saravanakumar (2011), dividend declaration is a critical decision, and dividends play a vital role in influencing the growth of the company through retained earnings and market value of the equity shares.

A number of studies have been carried out on dividend policy so far in different countries of the world (Agyei and Marfo-Yiadom, 2011; Ahmed and Javid, 2008; Al-Deehani, 2003; Al-Malkawi, Rafferty, and Pillai, 2010; Almazan, et al., 2010; Amidu and Abor, 2006; Anand, 2004; Anil and Kapoor, 2008; Arnott \& Asness 2003; Baker, Farrelly and Edelman, 1985; Baker and Powell, 2000; Chen and Dhiensiri, 2009; Farsio, Geary, and Moser, 2004; Gillet, Lapointe, and Raimbourg, 2008; Pandey, 2003). Alli, Khan and Ramirez (1993) supported the residual theory of dividends, pecking order argument, tax clientele argument, and the function of dividends in reducing the agency cost. However, the study of Denis and Osobov (2008) highlighted the agency cost-based lifecycle theories but kept reservation on signaling, clientele, and catering explanations for dividends. According to the demonstration of Hardin and Hill (2008), higher dividend payment can contribute towards reducing agency costs, reinforcing operating performance, executing a stock repurchase plan and assisting the access to short-term bank debt.

Researches intended to identify the expected influence of variables on the dividend policy of firms listed in different Stock Exchanges (Al-Twairjy, 2007; Baker, Rafique, 2012; Kim and Wonsiksul, 2010; Veit and Powell, 2001). The research of Moradi, Salehi \& Honarmand (2010) on all listed companies in the Tehran Stock Exchange revealed a positive relationship of dividend with profitability; and a negative relationship of dividend with $\mathrm{P} / \mathrm{E}$, beta rate and debt ratio. In another study, Kumar and Jha (2012) worked on the Indian Information Technology Sector listed at Bombay Stock Exchange (BSE) and found that net profit after tax, cash flow and amount of depreciation charged have significant impact on the equity dividend. Besides, Zameer, et al (2013) studied a sample of 27 foreign and domestic banks operating in Pakistan listed at different stock exchanges. The results of the research demonstrated that profitability, last year dividend and ownership structure have significant positive impact and liquidity has significant negative impact on the dividend payout of the banking industry.

Researchers intended to identify the influence of numerous variables on the dividend payout of corporations. Rozeff (1982) found an inverse relationship of dividend payment with a corporations' future growth in sales, beta rate, and management ownership ratio, and a positive relationship with the number of shareholders. The study also confirmed that a corporation's investment policies also affect its dividend policy. Dhanani (2005) identified that dividend policy of a company may vary significantly depending on firm size, industry sector, growth prospects, ownership structure, and information indiscretion. According to Banerjee, Gatchev and Spindr (2007), more liquid common stock holders are less likely to receive cash dividend and vice versa; and historical liquidity has a noteworthy part in the initiation and exclusion of dividend. Besides, Papadopoulos and Charalambidis (2007) found 
cash flow of the firm as the key determinant of dividend policy. As stated by Gupta and Banga (2010), a corporation's dividend payment decisions are influence by its leverage, liquidity, profitability, growth and ownership structure. Saravanakumar (2011) intended to determine the relationship of corporate dividend decisions with factors such as net profits, liquidity and reserve position, share prices, investors' expectations, volume of sales, windfall gains, etc. Poshakwale, Patra and Ow-Yong (2012) found positive relationship of size, profitability and liquidity with dividend payment, but negative relationship of investment opportunities, financial leverage and business risk. Badu (2013) found from his study that the major determinants of dividend policy of financial institutions in Ghana are age of the firm, collateral and liquidity. Table 1 reviews several factors related to corporate dividend policy and summarizes existing empirical evidence from the financial literatures.

Previous studies revealed that dividend policy may have impact on shareholders wealth or firm value (Adesola \& Okwong, 2009; Afza and Mirza, 2010; Aharony, and Swary, 1980; Amidu, 2007; Black and Scholes, 1974; Brennan and Thakor, 1990; Gordon, 1959; Malcolm and Wurgler, 2004 [a], [b]; Travlos, Trigeorgis and Vafeas, 2001). Such influence of dividend policy may be evident with respect to the firm's capital structure or investment decisions (Aivazian, Booth and Clearly, 2003; Baker, Veit and Powell, 2001; Faulkender, Milbourn, and Thakor, 2006); reduced agency problems (Bartram et al., 2009; DeAngelo, DeAngelo and Stulz, 2006); tax treatment (Alli, Khan and Ramirez, 1993; Howatt, et al., 2009; Singhania, 2006), etc. Akhigbe and Madura (1996) found positive drive of dividend instigations as well as negative impact of dividend omissions on share price in the long run. According to Ramachandran and Packkirisamy (2010), considering retained earnings as the lowest cost source of capital, managers may prefer lower dividend payout ratio in situations of higher capital requirements. However, they must also recognize investors' expectations about dividend yield, and thus, declare at least reasonable rate of dividend.

Empirical studies used different mathematical and statistical tools to examine dividend determinants. Kumar and Jha (2012) used regression models, Lintner's Model (1956), Darling's Model (1957), Brittain's cash flow Model (1966) and Brittain's explicit depreciation Model (1966). Other studies observed dividend determinants using Panel Regression (Amidu, 2007); Categorical and Regression analysis (Nissim \& Ziv, 2001), Generalized Method of Moments (Poshakwale, Patra and Ow-Yong, 2012), etc.

Numerous researches have spotted light on the dividend policy of pharmaceuticals industry. Khan (2012) has presented that dividend irrelevance theory is not pertinent to the chemical and pharmaceutical sector of Pakistan. Alam and Hossain (2012) made a comparative study on the dividend policy of pharmaceutical industry of UK and Bangladesh, and revealed that for the UK based companies, dividend rate is a positive function of leverage, profitability and market capitalization; whereas dividend rate is a reverse function of liquidity and growth. On the other hand, liquidity, leverage, profitability and market capitalization have negative influence on the dividend rate, while growth has positive influence in case of a Bangladeshi companies. However, in Bangladesh very few researches focused on the application of dividend policy theories on companies of a particular industry listed in a stock exchange. Moreover, in case of pharmaceutical industry of Bangladesh, a number of research efforts 
Table 1. Summary of empirical evidence on factors affecting corporate dividend policy

\begin{tabular}{|c|c|c|c|c|}
\hline Literature & Variable & Significant Positive & Significant Negative & Insignificant \\
\hline \multirow{2}{*}{ Adedeji, 1998} & Investment & & Negative & \\
\hline & Financial Leverage & Positive & & \\
\hline \multirow{3}{*}{$\begin{array}{l}\text { Agyei and } \\
\text { Marfo-Yiadom, } \\
2011\end{array}$} & Firm Performance & Significant Positive & & \\
\hline & Growth & Positive & & \\
\hline & Profitability & Positive & & \\
\hline \multirow{6}{*}{$\begin{array}{l}\text { Ahmed and Javid, } \\
2008\end{array}$} & Free Cash Flows & Positive & & \\
\hline & Ownership Concentration & Positive & & \\
\hline & Market Liquidity & Positive & & \\
\hline & Leverage & & Negative & \\
\hline & Market Capitalization & & Negative & \\
\hline & Size of the Firms & & Negative & \\
\hline \multirow{3}{*}{ Al-Twairjy, 2007} & Leverage & & Significant Negative & \\
\hline & Cash Per Share & Significant Positive & & \\
\hline & Share Book Value & Significant Positive & & \\
\hline $\begin{array}{l}\text { Al-Najjar and } \\
\text { Hussainey, } 2009\end{array}$ & $\begin{array}{l}\text { Number of Outside Directors on the } \\
\text { Board of Directors }\end{array}$ & & Negative & \\
\hline \multirow{4}{*}{$\begin{array}{l}\text { Amidu and Abor, } \\
2006\end{array}$} & Profitability & Significant Positive & & \\
\hline & Cash Flow & Significant Positive & & \\
\hline & $\operatorname{Tax}$ & Positive & & \\
\hline & Risk & & Negative & \\
\hline
\end{tabular}


Table 1. Summary of empirical evidence on factors affecting corporate dividend policy

\begin{tabular}{|c|c|c|c|c|}
\hline Literature & Variable & Significant Positive & Significant Negative & Insignificant \\
\hline & Institutional Holding & & Negative & \\
\hline & Growth & & Significant Negative & \\
\hline & Market-to-Book Value. & & Significant Negative & \\
\hline \multirow{2}{*}{ Amidu, 2007} & Return on Assets & & Negative & \\
\hline & Leverage & & Negative & \\
\hline $\begin{array}{l}\text { Chen and } \\
\text { Dhiensiri, } 2009\end{array}$ & Growth & & Negative & \\
\hline Diamond, 1989 & Age & & Negative & \\
\hline \multirow{2}{*}{ D’Souza, 1999} & Market Risk & & Significant Negative & \\
\hline & $\begin{array}{l}\text { Institutional Ownership of a Firm's } \\
\text { Shares }\end{array}$ & & Significant Negative & \\
\hline $\begin{array}{l}\text { Howatt et al., } \\
2009\end{array}$ & Changes in Earnings per Share & Positive & & \\
\hline $\begin{array}{l}\text { Jensen,Solberg,\& } \\
\text { Zorn, } 1992\end{array}$ & High Insider Ownership Firms & & Negative & \\
\hline \multirow{2}{*}{$\begin{array}{l}\text { La Porta et al., } \\
2000\end{array}$} & Growth & & Negative & \\
\hline & Liquidity/ Cash Flow & Positive & & \\
\hline $\begin{array}{l}\text { Nnadi \& Akpomi, } \\
2005\end{array}$ & Tax & Significant Positive & & \\
\hline \multirow{3}{*}{$\begin{array}{l}\text { Naceur,Goaied \& } \\
\text { Belanes, } 2006\end{array}$} & Profitability & Positive & & \\
\hline & Free Cash Flows & Positive & & \\
\hline & Growth & Positive & & \\
\hline
\end{tabular}


Table 1. Summary of empirical evidence on factors affecting corporate dividend policy

\begin{tabular}{|c|c|c|c|c|}
\hline Literature & Variable & Significant Positive & Significant Negative & Insignificant \\
\hline & Ownership Concentration & & & No Impact \\
\hline & Financial Leverage & & & No Impact \\
\hline & Liquidity of Stock Market & & Negative & \\
\hline & Size & & Negative & \\
\hline $\begin{array}{l}\text { Naceur et al., } \\
2006\end{array}$ & Liquidity/ Cash Flow & Positive & & \\
\hline $\begin{array}{l}\text { Nissim \& Ziv, } \\
2001\end{array}$ & Earnings Changes & Positive & & \\
\hline Pandey, 2003 & Earnings & Positive & & \\
\hline \multirow{6}{*}{$\begin{array}{l}\text { Patra, Poshakwale } \\
\text { \& Ow-Yong, } 2012\end{array}$} & Size & Positive & & \\
\hline & Profitability & Positive & & \\
\hline & Liquidity & Positive & & \\
\hline & Investment Opportunities & & Negative & \\
\hline & Financial Leverage & & Negative & \\
\hline & Business Risk & & Negative & \\
\hline \multirow{2}{*}{ Rozeff, 1982} & Agency Costs & & Negative & \\
\hline & Transactions Cost of External Financing & Positive & & \\
\hline \multirow{3}{*}{$\begin{array}{l}\text { Zameer, et al, } \\
2013\end{array}$} & Profitability & Significant Positive & & \\
\hline & Last Year Dividend & Significant Positive & & \\
\hline & Ownership Structure & Significant Positive & & \\
\hline
\end{tabular}


Table 1. Summary of empirical evidence on factors affecting corporate dividend policy

\begin{tabular}{|c|c|c|c|c|}
\hline Literature & Variable & Significant Positive & Significant Negative & Insignificant \\
\hline \multirow{6}{*}{$\begin{array}{l}\text { Zameer, et al, } \\
2013\end{array}$} & Liquidity & & Significant Negative & \\
\hline & Size & & & No Impact \\
\hline & Leverage & & & No Impact \\
\hline & Agency Cost & & & No Impact \\
\hline & Growth & & & No Impact \\
\hline & Risk & & & No Impact \\
\hline
\end{tabular}

have been employed so far, especially focusing on the performance, problems and prospects, dividend determinants, etc. (Alam and Hossain, 2012; Azam, and Richardson, 2010; DCCI, 2008; Habib, and Alam, 2011; Islam and Mili, 2012; Majumder and Rahman, 2011; Saad, 2012; VanDuzer, 2003; World Bank, 2008). However, studies hardly worked on the pharmaceuticals dividend policy determinants, particularly focusing on the interest of the stock market investors.

Unlike earlier studies, this study attempted to examine the dividend policy determinants of the pharmaceuticals and chemicals industries, and guide the equity market investors in making their investment decisions. In this attempt, this study is also a unique one to incorporate the chemicals industry along with the pharmaceuticals industry as both the industries constitute the pharmaceuticals and chemicals sector listed in the stock market of Bangladesh.

\section{Methodology}

This study is an investigative one and it deliberated largely on the analysis of dividend policy and its determinants in the context of the pharmaceuticals and chemicals industries in Bangladesh. At present 28 companies are listed under the pharmaceuticals and chemicals sector in DSE. The data set consists of a sample of 15 companies among these listed companies. Table 2 presents a list of the sample companies as well as their short names used in the data set. The research covered a time period of fourteen years from 2001 to 2014. The study used mostly secondary data and the database has been developed based on the secondary data collected from the annual reports of concerned companies, monthly publications of DSE, websites of DSE and relevant pharmaceuticals and chemicals companies, etc. Various books, journals and online publications are consulted in developing the variables and attributes. Pertinent information from such sources also supported the construction of the theoretical framework related to the dividend policy of the 
pharmaceuticals and chemicals industries, and the determinants thereof.

Table 2. Sample Pharmaceuticals and Chemicals Companies and Short Names Used

\begin{tabular}{|c|l|l|c|l|l|}
\hline $\begin{array}{c}\text { S1. } \\
\text { No. }\end{array}$ & \multicolumn{1}{|c|}{ Company Name } & $\begin{array}{c}\text { Short } \\
\text { Name }\end{array}$ & $\begin{array}{c}\text { Sl. } \\
\text { No. }\end{array}$ & \multicolumn{1}{|c|}{ Company Name } & \multicolumn{1}{|c|}{ Short Name } \\
\hline 1 & ACI Limited & ACI & 9 & Renata Limited & RENATA \\
\hline 2 & Ambee Pharmaceuticals Ltd. & AMBPH & 10 & $\begin{array}{l}\text { Square Pharmaceuticals } \\
\text { Limited }\end{array}$ & SQRPH \\
\hline 3 & Beximco Pharmaceuticals Ltd (BPL) & BEXPH & 11 & Reckitt Benckiser & RECKBEN \\
\hline 4 & Glaxo Smithkline & GLAXO & 12 & Kohinnor Chemicals & KOCHEM \\
\hline 5 & $\begin{array}{l}\text { The Ibn-Sina Pharmaceutical Industry } \\
\text { Ltd. }\end{array}$ & IBNSINA & 13 & Keya Cosmetics & KEYACOS \\
\hline 6 & Libra Infusion Ltd. & LIBRA & 14 & Beximco Synthetics & BSYNTH \\
\hline 7 & Orion Infusion Ltd. & ORION & 15 & Imam Button & IBUTTON \\
\hline 8 & Pharma Aids & PHAID & & & \\
\hline
\end{tabular}

The study indented to recognize and evaluate the relative explanatory power of firm characteristics on dividend policy. Particularly this research explored the influence of firm-specific factors (size, growth, liquidity, profitability, last year's dividend, $\mathrm{P} / \mathrm{E}$ ratio) on dividend payout. The study involved the tabulation, analysis and interpretation of collected data; and the data analysis process consists of descriptive statistics, correlation matrix and multiple linear regression analysis. In order to find out the key factors that affect the dividend policy of the firms, the research took a number of hypotheses and used multiple regression analysis to test those hypotheses statistically.

\section{Determinants of Dividend Policy of Pharmaceuticals and Chemicals Industries in Bangladesh}

\subsection{Hypothesis Development}

The key intent of this study is to recognize the determinants of dividend policy of the pharmaceuticals and chemicals companies in Bangladesh. Variables and their proxies are selected on the basis of empirical researches carried out worldwide to show the relationship between dividend policy and its determining factors. The variables focused in this study include: firm size, firm growth, liquidity, profitability, last year's dividend, $\mathrm{P} / \mathrm{E}$ ratio, ownership structure, firm age, market share, and risk.

\subsubsection{Dividend Payout}

Only final cash dividends paid by the companies have been considered here, and stock dividend and stock repurchases by the companies have been ignored. Previous studies mostly used dividend payout ratio as a determinant of dividend (Chen, Jian and $\mathrm{Xu}, 2009$; Holder et al., 1998; Jensen, Solberg and Zorn, 1992; Lloyd, Jahera and Page, 1985). This study also used dividend payout ratio as the dependent variable because the dividend payout ratio considers both dividend payout and dividend retention. 


\subsubsection{Firm Size}

Firm size is one of the most acknowledged determinants of a firm's dividend policy. "The idea that firm size and dividend payout are positively correlated is generally accepted by many financial economists" (Redding, 1997). The result of this study shows that large companies are indeed more likely to pay dividends than small companies. Larger firms have better access to capital market which allows them to be less dependent on retained earnings for internal financing and thus, pay more dividends. The positive relationship between firm size and dividend payout is also supported by a growing number of studies (Adedeji, 1998; Al-Kuwari, 2007; Al-Shubiri, 2011; Al-Twaijry, 2007; Anupam, 2012; Gaver and Gaver, 1993; Mahira, 2012; Vogt, 1994). Other studies related dividend and firm size to transaction cost (Alli, Khan and Ramirez, 1993). Large firms can raise financing by paying lower transaction costs than smaller firms, and can pay more dividends. On the basis of the theoretical outline and the literature review, the first hypothesis is developed as:

\section{Hypothesis 1: There is a significant association between firm size and dividend payout.}

\subsubsection{Firm Growth}

Firm growth enlightens historical achievement of a firm as well as predicts what is expected to materialize in future. Different stages of development and growth of the firm influence dividend payout. A number of studies revealed inverse relationship between dividend payment and growth opportunities (Gaver, and Gaver, 1993; Higgins, 1981). Firms having higher growth opportunities use internally generated funds to finance their investment projects and hence, cut or reduce dividend payments. On the other hand, firms having low growth opportunities and fewer investment projects are exposed to low incentive to retain more. Such firms remove resources by paying more dividends and reduce the agency costs of free cash flows (Al-Malkawi, 2007; D’Souza, 1999). Kania (2005) found positive correlation between growth and level of dividend payment. Following empirical research, sales/revenues is used as a proxy variable for growth opportunities in this study. Since previous studies portray both negative and positive relationship between the dividend and sales growth, the second hypothesis is:

Hypothesis 2: There is a significant relationship between firm growth and dividend payout.

\subsubsection{Liquidity}

Liquidity position of a company for dividend payment is another vital determinant of dividend policy. A number of studies found positive relationship between liquidity and payout ratio (Ahmed and Javed, 2008; Ahmed and Carlos, 2008; Amidu and Abor, 2006; Anil and Kapoor, 2008; Benito and Young, 2001; Gunasekarage and Power, 2006). This positive relationship explains that firms with high liquidity are in position to pay higher dividends, while firms with poor liquidity are forced to reduce or cut dividends. Some other studies found reverse relationship between liquidity and dividend payout ratios (Barclay et al. 1995; Marfo-Yiadom and Agyei, 2011). The negative relationship explains that increasing dividend payout ratios reduce the liquidity; because higher return on equity stimulates the firm to retain more for reinvestment purpose and thus, lower the dividend. The third hypothesis of 
this study is:

Hypothesis 3: Liquidity has a significant relationship with dividend payout.

\subsubsection{Profitability}

Profitability can be termed as the capacity of a firm to generate profit. Profitability is exposed to be one of the most critical determinants of the dividend policy of firms (Al-Najjar and Hussainey, 2009). Highly profitable firms can pay more dividends, while less profitable firms find it difficult to pay dividends. The studies of Linter, 1956; Baker et al. 1985; Matthias, Nnadi and Meg, 2008 depicted that dividend payment pattern of firms are influenced by current earnings and the previous year dividends. However, Pruitt and Gitman, 1991 argued that both current and past year profits determine dividend payments. A considerable number of other studies also found positive relationship between dividend payout and profitability of firms (Amidu and Abor, 2006; Baker and Powell, 2000; Fama and French, 2001; Han, Lee and Suck, 1999; Jensen, Solberg and Zorn, 1992; Kohli, Sharma and Sood, 2011). Based on the theory and past research findings, the fourth hypothesis is:

Hypothesis 4: There is a significant relationship between profitability and dividend payout.

\subsubsection{Last year dividend}

Rehman (2012) found that last year dividend has significant impact on the dividend payout of current period, and firms strive to increase the payout ratio for the subsequent years rather than reducing it. According to Zameer et al., 2013 and Lintner, 1965, firms try to maintain previous pay out pattern to ensure a stable dividend payout and to progressively increase the dividend payout ratio. These findings point out that previous year dividends positively affect current year dividends and therefore, the fifth hypothesis becomes:

Hypothesis 5: Last year dividend has a significant relationship with dividend payout.

\subsubsection{Price to Earnings $(\mathrm{P} / \mathrm{E})$ ratio}

Scholarly research considered dividend payout of a company to have substantial impact on the price of its shares in the equity market (Banz, 1981; Howatt et al., 2009; Miller and Modigliani, 1961; Ohlson and Juettner-Nauroth, 2005). Studies also focused on the relationship between earnings of a corporation and its dividend policy (Pandey, 2003; Nissim \& Ziv, 2001). Based on the empirical literature, the sixth hypothesis becomes:

Hypothesis 6: There is significant relationship between P/E ratio and dividend payout.

Besides the variables scrutinized as determinants of dividend payout, some other variables such as ownership structure, firm age, market share and risk have been used in the study as control variables.

\subsection{Model Specification}

Linear Multiple Regression model has been used for testing the hypotheses presented here. The dependent variable of the model is dividend payout ratio (DIV) and the independent variables are firm size (SIZE), firm growth (GRTH), liquidity (LIQ), profitability (PROF), last 
year dividend (DIVt-1) and price to earnings ratio (P/E Ratio). The control variables used here are ownership structure (OWN), firm age (AGE), market share (MKTSHR) and risk (RISK). Therefore, the regression equation is as follows:

$$
\begin{gathered}
\mathrm{DIV}=\beta_{0}+\beta_{1}(\mathrm{SIZE})+\beta_{2}(\mathrm{GRTH})+\beta_{3}(\mathrm{LIQ})+\beta_{4}(\mathrm{PROF})+\beta_{5}(\mathrm{DIVt}-1)+\beta_{6}(\mathrm{P} / \mathrm{E} \text { Ratio })+ \\
\beta_{7}(\mathrm{OWN})+\beta_{8}(\mathrm{AGE})+\beta_{9}(\mathrm{MKTSHR})+\beta_{10}(\mathrm{RISK})+\mathrm{e}_{0}
\end{gathered}
$$

\subsection{Variable Definition}

1. Firm size (SIZE) is an algebraic expression of the natural logarithm of firms' total asset.

2. Growth rate (GROW) is measured as the growth rate of sales

3. Liquidity (LIQ) is measured as a natural logarithm of a firm's cash flow from operations.

4. Return on Equity (ROE) has been used as a proxy for profitability (PROF). ROE is calculated as: Return on Equity = Net Income/Shareholder's Equity.

5. Last year's dividend is used as a proxy for last year dividend (DIVt-1)

6. Price to earnings ratio $(\mathrm{P} / \mathrm{E}$ Ratio $)$ is calculated as: $\mathrm{P} / \mathrm{E}$ ratio $=$ Price per share/Earnings per share (EPS)

7. Natural logarithm of No. of shareholders is used as a proxy for ownership structure (OWN)

8. Age of each of the sample firms (AGE) is considered from the year of its listing in the DSE till 2014. Firm AGE is measured as a natural logarithm of a firm's listing age in DSE.

9. Market share (MKTSHR) is calculated as sales revenue of individual firms for a given year divided by the total sales revenue of all the firms included in the data set for the same year.

10. Variability in profitability is measured by the standard deviation of ROE, which is used as proxy for risk (RISK)

11. Dividend is expressed as dividend payout ratio which is calculated as dividend divided by net income of the firm.

\section{Empirical Analysis}

The empirical research griped an examination of determinants of dividend policy of the pharmaceuticals and chemicals industries of Bangladesh. The result of the study is illustrated through the relationship of a number of scrutinized variables to dividend payout, an indicator of dividend policy.

\subsection{Descriptive Statistics}

Table 3 depicts the descriptive statistics of data after normalization of firm size, liquidity, last year's dividend, number of shareholders and firm listing age. The table lists the Mean, Median, Standard Deviation (SD), sample Variance (Variance), Minimum (Min) and Maximum (Max) values of each of the variables.

The mean of the dividend payout ratio of the sample firms signifies that on an average $49 \%$ 
Table 3. Descriptive Statistics

\begin{tabular}{|l|l|l|l|l|l|l|l|l|l|l|l|}
\hline & DIV & $\begin{array}{c}\text { SIZE } \\
(N . \\
\text { Log })\end{array}$ & GRTH & $\begin{array}{c}\text { LIQ } \\
(N . \\
\text { Log })\end{array}$ & $\begin{array}{c}\text { PROF } \\
(\text { ROE })\end{array}$ & $\begin{array}{c}\text { DIVt-1 } \\
(N . \\
\text { Log })\end{array}$ & $\begin{array}{c}\text { P/E } \\
\text { Ratio }\end{array}$ & $\begin{array}{c}\text { OWN } \\
(N . \\
\text { Log })\end{array}$ & $\begin{array}{c}\text { AGE } \\
(N . \\
\text { Log })\end{array}$ & MKTSHR & RISK \\
\hline Mean & 0.49 & 9.03 & 0.15 & 7.07 & 0.16 & 6.84 & 46.3 & 3.6 & 1.23 & 0.07 & 0.25 \\
\hline Median & 0.43 & 9.01 & 0.13 & 7.81 & 0.14 & 7.3 & 16.56 & 3.62 & 1.26 & 0.04 & 0.06 \\
\hline SD & 0.49 & 0.68 & 0.23 & 2.73 & 0.48 & 2.09 & 108.7 & 0.71 & 0.25 & 0.08 & 0.39 \\
\hline $\begin{array}{l}\text { Sample } \\
\text { Variance }\end{array}$ & 0.24 & 0.46 & 0.05 & 7.43 & 0.23 & 4.36 & 11818 & 0.51 & 0.06 & 0.01 & 0.16 \\
\hline Minimum & -1.23 & 7.76 & -0.36 & 0 & -1.87 & 0 & -95.4 & 0 & 0 & 0 & 0.01 \\
\hline Maximum & 4.66 & 10.46 & 1.4 & 9.75 & 5.44 & 8.97 & 723.5 & 4.97 & 1.58 & 0.29 & 1.47 \\
\hline Count & 210 & 210 & 210 & 210 & 210 & 210 & 210 & 210 & 210 & 210 & 210 \\
\hline $\begin{array}{l}\text { Confidence } \\
\text { Level (95\%) }\end{array}$ & 0.07 & 0.09 & 0.03 & 0.37 & 0.07 & 0.28 & 14.79 & 0.1 & 0.03 & 0.01 & 0.05 \\
\hline
\end{tabular}

of the net profits are distributed by the firms as dividend. The standard deviation of dividend payout ratio is $49 \%$, which indicates a high dispersion of the dividend payout ratio among the firms in the industry. Average $\mathrm{P} / \mathrm{E}$ ratio of the industry is 46.30 with a significantly high standard deviation of 108.71. Industry average profitability, as measured by ROE is 0.1644793 ; while, company ROE is maximum 5.44 and minimum -1.87. Maximum market share held by a particular company is $29.12 \%$. On the other hand, the minimum market share constitutes $0.054 \%$. Industry average growth rate is $14.55 \%$, whereas, average risk is about $25 \%$.

\subsection{Correlation Matrix}

Before the multiple regression is run, the existence of multicollinearity among all employed Table 4. Correlation Matrix

\begin{tabular}{|c|c|c|c|c|c|c|c|c|c|c|c|}
\hline & DIV & $\begin{array}{l}\text { SIZE } \\
(N . \\
\text { Log }) \\
\end{array}$ & $\begin{array}{c}\text { GRT } \\
\mathrm{H} \\
\end{array}$ & $\begin{array}{c}\text { LIQ } \\
(N . \\
\text { Log) }\end{array}$ & $\begin{array}{l}\text { PROF } \\
(R O E)\end{array}$ & $\begin{array}{c}\text { DIVt-1 } \\
(N . \\
\text { Log) }\end{array}$ & $\begin{array}{c}P / E \\
\text { Ratio }\end{array}$ & $\begin{array}{c}\text { OW } \\
\mathrm{N} \\
(N . \\
\text { Log) }\end{array}$ & $\begin{array}{c}\text { AGE } \\
(N . \\
\text { Log) }\end{array}$ & $\begin{array}{l}\text { MKT } \\
\text { SHR }\end{array}$ & RISK \\
\hline DIV & 1 & & & & & & & & & & \\
\hline SIZE $(N . L o g)$ & -0.21 & 1 & & & & & & & & & \\
\hline GRTH & -0.02 & 0.07 & 1 & & & & & & & & \\
\hline LIQ (N. Log) & 0.02 & 0.4 & 0.19 & 1 & & & & & & & \\
\hline PROF (ROE) & -0.07 & 0.04 & 0.1 & 0.14 & 1 & & & & & & \\
\hline DIVt-1 (N. Log) & 0.12 & 0.42 & 0.24 & 0.34 & 0.19 & 1 & & & & & \\
\hline P/E Ratio & 0.18 & -0.02 & 0 & 0.1 & 0.05 & 0.1 & 1 & & & & \\
\hline OWN (N. Log) & -0.06 & 0.54 & 0.1 & 0.26 & 0.01 & 0.25 & 0.08 & 1 & & & \\
\hline AGE (N. Log) & -0.05 & 0.26 & -0.08 & 0.27 & 0.09 & 0.24 & 0.05 & 0.05 & 1 & & \\
\hline MKTSHR & -0.18 & 0.78 & 0.09 & 0.38 & 0.04 & 0.44 & -0.12 & 0.49 & 0.17 & 1 & \\
\hline RISK & 0 & -0.29 & 0.04 & -0.04 & 0.14 & -0.09 & 0.13 & 0.01 & 0.05 & -0.26 & 1 \\
\hline
\end{tabular}


independent variables and the dependent variable has been tasted using correlation matrix. The correlation matrix, comprised of the normalized value of the variables, has been presented in Table 4. The matrix illustrates low correlation among the scrutinized variables (less than 0.8 ) which symbolizes no multicollinearity problem.

\subsection{Multiple Regression Analysis}

The study investigates the factors affecting the dividend policy of pharmaceuticals and chemicals industries by testing a number of hypotheses using multiple regression analysis. Summary statistics of the regression analysis is illustrated in Table 5. The coefficient of determination $\left(\mathrm{R}^{2}\right)$ is 0.158394789 which indicates that about $15.83 \%$ of the changes in the dependent variable, that is dividend payout, are explained by the changes in the independent and control variables of the model.

Among the dependent variables, firm size (SIZE) has low p-value $(<0.05)$ which indicates the acceptance of the first hypothesis. Therefore, dividend payout of Bangladesh pharmaceuticals and chemicals industries depends significantly on the size of a firm. The coefficient of firm size is -0.23177 which indicates that if firm size increase by 1 unit, dividend payout decreases by 0.23 units. Therefore, dividend payout of Bangladesh pharmaceuticals and chemicals industries has significant negative relationship with size of firm. The result supports the findings of Ahmed and Javid, (2008). Hence, as firms become larger, investors should expect a lower divided and vice versa.

Last year's dividend (DIVt-1) is another variable having a low p-value which indicates that the fifth hypothesis has been accepted. The positive coefficient of the variable $(0.0679)$ indicates a positive relationship between dividend payout and DIVt-1. Thus, dividend payout has significant positive relationship with last year's dividend payment by the firms. This outcome is consistent with Naceu, Goaied and Belanes's (2006), who analyzed Tunisian firms and found that the level of dividend payment depends on both the current earnings as well as historical dividends. Thus, more stable earnings and rapid growth of profitable companies contribute to larger free cash flows and assist in paying higher dividend.

Conversely, firm growth, liquidity, profitability and $\mathrm{P} / \mathrm{E}$ ratio have larger p-values $(\geq 0.05)$ which leads to the rejection of the second, third, fourth and sixth hypotheses. Thus, firm growth, liquidity, profitability and $\mathrm{P} / \mathrm{E}$ ratio have been found to have no significant relationship with dividend payout of the pharmaceuticals and chemicals industries. Empirically researchers explored liquidity to have no significant impact on dividend policy (Adedeji, 1998; Anupam, 2012). Besides, Zameer, et al (2013) explored firm growth to have no impact on dividend payout.

In addition, all the control variables in the study have higher $\mathrm{p}$ values which represent that dividend policy of a firm does not depend directly on the factors like No. of shareholders, firm age, market share and risk. Therefore, changes in these variables do not impact the dividend payout of the industry. 
Table 5. Multiple Regression Analysis

SUMMARY OUTPUT

\begin{tabular}{lr}
\hline \multicolumn{2}{c}{ Regression Statistics } \\
\hline Multiple R & 0.4 \\
R Square & 0.16 \\
Adjusted R Square & 0.12 \\
Standard Error & 0.46 \\
Observations & 210 \\
\hline
\end{tabular}

ANOVA

\begin{tabular}{|c|c|c|c|c|c|}
\hline & $d f$ & SS & $M S$ & $F$ & $\begin{array}{c}\text { Significance } \\
F \\
\end{array}$ \\
\hline Regression & 10 & 7.98 & 0.8 & 3.75 & 0.00 \\
\hline Residual & 199 & 42.39 & 0.21 & & \\
\hline Total & 209 & 50.37 & & & \\
\hline
\end{tabular}

\begin{tabular}{|c|c|c|c|c|c|c|c|c|}
\hline & \multicolumn{4}{|c|}{ Standard } & \multirow{2}{*}{$\begin{array}{l}\text { Lowe } \\
\text { r 95\% }\end{array}$} & \multirow{2}{*}{$\begin{array}{c}\text { Upper } \\
95 \% \\
\end{array}$} & \multirow{2}{*}{$\begin{array}{l}\text { Lower } \\
95.0 \%\end{array}$} & \multirow{2}{*}{$\begin{array}{l}\text { Upper } \\
95.0 \%\end{array}$} \\
\hline & Coefficients & Error & t Stat & P-value & & & & \\
\hline Intercept & 1.99 & 0.67 & 2.96 & 0 & 0.67 & 3.31 & 0.67 & 3.31 \\
\hline \multicolumn{9}{|l|}{ Firm Size (Natural } \\
\hline $\log )$ & -0.23 & 0.08 & -2.73 & 0.01 & -0.4 & -0.06 & -0.4 & -0.06 \\
\hline Firm Growth & -0.14 & 0.15 & -0.95 & 0.34 & -0.43 & 0.15 & -0.43 & 0.15 \\
\hline \multicolumn{9}{|l|}{ Liquidity (Natural } \\
\hline $\log )$ & 0.02 & 0.01 & 1.35 & 0.18 & -0.01 & 0.05 & -0.01 & 0.05 \\
\hline Return on Equity & -0.11 & 0.07 & -1.6 & 0.11 & -0.25 & 0.03 & -0.25 & 0.03 \\
\hline Last year's dividend & & & & & & & & \\
\hline (Natural Log) & 0.07 & 0.02 & 3.67 & 0 & 0.03 & 0.1 & 0.03 & 0.1 \\
\hline P/E Ratio & 0 & 0 & 1.94 & 0.05 & 0 & 0 & 0 & 0 \\
\hline No. of shareholders & & & & & & & & \\
\hline (Natural Log) & 0.05 & 0.06 & 0.96 & 0.34 & -0.06 & 0.16 & -0.06 & 0.16 \\
\hline Firm Listing Age & & & & & & & & \\
\hline (Natural Log) & -0.08 & 0.14 & -0.57 & 0.57 & -0.36 & 0.2 & -0.36 & 0.2 \\
\hline Market Share & -0.85 & 0.73 & -1.17 & 0.24 & -2.28 & 0.58 & -2.28 & 0.58 \\
\hline Risk & -0.11 & 0.09 & -1.26 & 0.21 & -0.29 & 0.06 & -0.29 & 0.06 \\
\hline
\end{tabular}

\section{Contribution and Practical Implications}

Numerous research works have been carried out in this field, especially covering the developed world. Such studies have noteworthy contribution to the financial literature of developing countries like Bangladesh. However, their outcomes may not have direct implications in Bangladesh context due to dissimilarity of cultural, political, and economic 
arrangements. The upshot of the research is expected to offer unique hub to investors, especially in their security selection process. Moreover, policy makers and management authority of Bangladeshi pharmaceuticals and chemicals companies may want to re-sketch their dividend policies based on the outcomes of the study in order to draw the attention of equity investors towards their companies. Investment consultants can edify themselves based on the outcomes of the study and guide their clients accordingly. Regulators in the stock market can also be aware of the impact of the examined factors on the dividend payout of such a promising sector listed in Bangladesh stock market; which may help them in updating their regulations with respect to dividend issues, and thus, maintaining stability in the stock market.

\section{Conclusion}

Dividend policy can be marked as a vital research arena in corporate finance. This research is an endeavor to determine the factors that affect the dividend policy of the firms in the pharmaceuticals and chemicals industries. The study explores that firm size has a significant and negative effect on the dividend policy of the pharmaceuticals and chemicals industries. In addition, last year's divided is confirmed to have a significant positive impact on the dividend payout of the firms. However, the study found no significant relationship of dividend payment with firm growth, liquidity, profitability and P/E ratio. Based on the findings of the research, investors can be suggested to focus exclusively on the size of the corporations and their previous dividend payment trend while investing in the shares of the companies in these industries.

\section{Limitations of the Study and Scope for Further Research}

The research is based on pharmaceuticals and chemicals companies listed in DSE. Compared to the stock markets of developed countries around the world, DSE is at its emerging stage. The Securities and Exchange Commission (SEC) also needs to be more structured and regulated. Corporate governance is yet to be properly implemented here. Different manipulation, inconsistency, misspecification and misrepresentation in data may create misleading information for investors, analysts, professionals and researchers. For this study, most of the data were collected from the financial statements of the sample companies, where data manipulation is a common phenomenon. Due to the absence of strong corporate governance, regulatory bindings and accountability to DSE and SEC, some companies get the opportunity to manipulate data, which is not the concern of this study. Moreover, although there has been an ample amount of research regarding industry dividend policy, limited substantial work has been done thus far in Bangladesh on the dividend policy determinants of pharmaceuticals companies. Therefore, an insufficiency of empirical literature exists in this arena.

The study attempted to paint the set of factors with a deliberately large brush, given its objective is to explore the dividend determinants of the pharmaceuticals and chemicals industries, especially to guide the stock market investors. Certainly more work lies ahead to add to explanations for why some of the factors affect the dividend policy of the industries, while others have no significant impact thereon. Further research can also be done in order to 
identify the stock market investors' view on dividend policy. In this regard, portfolios of various investors can be investigated and analyzed in terms of their demographic and other behavioral features. In addition, research efforts can also be employed including more variables for meticulous understanding of the determinants of dividend policy in the industry.

\section{References:}

Adedeji, A. (1998). Does the pecking order hypothesis explain the dividend payout ratios of firms in the UK?. Journal of Business Finance \& Accounting, 25(9-10), 1127-1155. https://doi.org/10.1111/1468-5957.00230

Adesola, W. A., \& Okwong, A. E. (2009). An empirical study of dividend policy of quoted companies in Nigeria. Global Journal of Social Sciences, 8(1), 85-101. https://doi.org/10.4314/gjss.v8i1.48907

Agyei, S. K., \& Marfo-Yiadom, E. (2011). Dividend policy and bank performance in Ghana. International Journal of Economics and Finance, 3(4), 202. https://doi.org/10.5539/ijef.v3n4p202

Agyemang Badu, E. (2013). Determinants of Dividend Payout Policy of listed Financial Institutions in Ghana. Research Journal of Finance and Accounting, 4(7).

Aharony, J., \& Swary, I. (1980). Quarterly dividend and earnings announcements and stockholders' returns: An empirical analysis. The Journal of Finance, 35(1), 1-12. https://doi.org/10.1111/j.1540-6261.1980.tb03466.x

Ahmed, H., \& Javid, A. Y. (2008). Dynamics and determinants of dividend policy in Pakistan (evidence from Karachi stock exchange non-financial listed firms). International Research Journal of Finance and Economics Issue, 25, 148-171.

Aivazian, V., Booth, L., \& Cleary, S. (2003). Do emerging market firms follow different dividend policies from US firms?. Journal of Financial research, 26(3), 371-387. https://doi.org/10.1111/1475-6803.00064

Akhigbe , A. \& Madura, J. (1996). Dividend policy and corporate performance, Journal of Business Finance \& Accounting, $23 \quad(9-10), \quad 1267 \quad-1287$. https://doi.org/10.1111/1468-5957.00079

Alam, M. Z., \& Hossain, M. E. (2012). Dividend policy: a comparative study of UK and Bangladesh based companies. IOSR Journal of Business and Management, 1(1), 57-67. https://doi.org/10.9790/487X-0115767

Al-Deehani, T. M. (2003). Determinants of dividend policy: the case of Kuwait. Journal of Economic and Administrative Sciences, 19(2), 59-76. https://doi.org/10.1108/10264116200300006

Al-Kuwari, D. (2009), Determinants of the Dividend Payout Ratio of Companies Listed on Emerging Stock Exchanges: The Case of the Gulf Cooperation Council (GCC) Countries. Global Economy \& Finance Journal, 2(2), 38-63. 
Al-Malkawi, H. A. N., Rafferty, M., \& Pillai, R. (2010). Dividend policy: A review of theories and empirical evidence. International Bulletin of Business Administration, 9(1), 171-200.

Al-Najjar, B., \& Hussainey, K. (2009). The association between dividend payout and outside directorships. Journal of Applied Accounting Research, 10(1), 4-19. https://doi.org/10.1108/09675420910963360

Al-Shubiri, F. N. (2011). Determinants of changes dividend behavior policy: Evidence from the Amman Stock Exchange. Far East Journal of Psychology and Business, 4(1), 1-15.

Al-Twaijry, A. A. (2007). Dividend policy and payout ratio: evidence from the Kuala Lumpur stock exchange. The Journal of Risk Finance, 8(4), 349-363. https://doi.org/10.1108/15265940710777306

Alli, K. L., Khan, A. Q., \& Ramirez, G. G. (1993). Determinants of corporate dividend policy: A factorial analysis. Financial Review, 28(4), 523-547. https://doi.org/10.1111/j.1540-6288.1993.tb01361.x

Almazan, A., De Motta, A., Titman, S., \& Uysal, V. (2010). Financial structure, acquisition opportunities, and firm locations. The Journal of Finance, 65(2), 529-563. https://doi.org/10.1111/j.1540-6261.2009.01543.x

Amidu, M., \& Abor, J. (2006). Determinants of dividend payout ratios in Ghana. The journal of risk finance, $7(2), 136-145$. https://doi.org/10.1108/15265940610648580

Amidu, M. (2007). How does dividend policy affect performance of the firm on Ghana Stock Exchange?. Investment Management \& Financial Innovations, 4(2), 104 - 112.

Anil, K., \& Kapoor, S. (2008). Determinants of dividend payout ratios-a study of Indian information technology sector. International Research Journal of Finance and Economics, 15(1), 63-71.

Anand, M. (2004). Factors influencing dividend policy decisions of corporate India. The icfai Journal of Applied Finance, 10 (2), 5-16.

Arnott, R. D., \& Asness, C. S. (2003). Surprise! Higher dividends= higher earnings growth. Financial Analysts Journal, 59(1), 70-87. https://doi.org/10.2469/faj.v59.n1.2504

Azam, M. M., \& Richardson, K. (2010). Pharmaceutical Patent Protection and Trips Challenges for Bangladesh: An Appraisal of Bangladesh's Patent Office and Department of Drug Administration. Bond Law Review, 22(2), 1-15.

Baker, H. K., Farrelly, G. E., \& Edelman, R. B. (1985). A survey of management views on dividend policy. Financial management, 14(4), 78-84. https://doi.org/10.2307/3665062

Baker, H. K., \& Powell, G. E. (2000). Determinants of corporate dividend policy: a survey of NYSE firms. Financial Practice and education, 10(1), 29-40.

Baker, H. K., \& Powell, G. E. (1999). How corporate managers view dividend 
policy. Quarterly Journal of Business and Economics, 17-35.

Baker, H. K., Veit, E. T., \& Powell, G. E. (2001). Factors influencing dividend policy decisions of Nasdaq firms. Financial Review, 36(3), 19-38. https://doi.org/10.1111/j.1540-6288.2001.tb00018.x

Baker, M., \& Wurgler, J. (2004). Appearing and disappearing dividends: The link to catering incentives. Journal of Financial 271-288. https://doi.org/10.1016/j.jfineco.2003.08.001

Baker, M., \& Wurgler, J. (2004). A catering theory of dividends. The Journal of Finance, 59(3), 1125-1165. https://doi.org/10.1111/j.1540-6261.2004.00658.x

Banerjee, S., Gatchev, V. A., \& Spindt, P. A. (2007). Stock market liquidity and firm dividend policy. Journal of Financial and Quantitative Analysis, 42(02), 369-397. https://doi.org/10.1017/S0022109000003318

Banz, R. W. (1981). The relationship between return and market value of common stocks. Journal of financial economics, 9(1), 3-18. https://doi.org/10.1016/0304-405X(81)90018-0

Barclay, M. J., Smith, C. W., \& Watts, R. L. (1995). The determinants of corporate leverage and dividend policies. Journal of applied corporate finance, 7(4), 4-19. https://doi.org/10.1111/j.1745-6622.1995.tb00259.x

Ben Naceur, S., Goaied, M., \& Belanes, A. (2006). On the determinants and dynamics of dividend policy. International review of Finance, 6(1-2), 1-23. https://doi.org/10.1111/j.1468-2443.2007.00057.x

Benito, A., \& Young, G. (2003). Hard times or great expectations? Dividend omissions and dividend cuts by UK firms. Oxford Bulletin of Economics and Statistics, 65(5), 531-555. https://doi.org/10.1111/j.1468-0084.2003.00060.x

Black, F. (1976). The dividend puzzle. The Journal of Portfolio Management, 2(2), 5-8. https://doi.org/10.3905/jpm.1976.408558

Black, F., \& Scholes, M. (1974). The effects of dividend yield and dividend policy on common stock prices and returns. Journal of financial economics, 1(1), 1-22. https://doi.org/10.1016/0304-405X(74)90006-3

Brennan, M. J., \& Thakor, A. V. (1990). Shareholder preferences and dividend policy. The Journal of Finance, 45(4), 993-1018. https://doi.org/10.1111/j.1540-6261.1990.tb02424.x

Brittain, J. A. (1966). Corporate dividend policy. Brookings institution.

Brown, P. S., Bartram, S., How, J., \& Verhoeven, P. (2009). Agency Conflicts and Corporate Payout Policies: A Global Study.

Chen, D., Jian, M., \& Xu, M. (2009). Dividends for tunneling in a regulated economy: The case of China. Pacific-Basin Finance Journal, 17(2), 209-223. https://doi.org/10.1016/j.pacfin.2008.05.002 
Chen, J. \& Dhiensiri, N. (2009). Determinants of dividend policy: the evidence from New Zealand. International Research Journal of Finance and Economics, 34(34), 18-28.

Darling, P. G. (1957). The influence of expectations and liquidity on dividend policy. Journal of Political Economy, 65(3), 209-224. https://doi.org/10.1086/257920

DCCI (Dhaka Chamber of Commerce and Industries). (2008). Supply and demand survey on pharmaceutical and natural products - Bangladesh. Asia Health Care. Malaysia, March, 2008. International Trade Centre.

DeAngelo, H., DeAngelo, L., \& Stulz, R. M. (2006). Dividend policy and the earned/contributed capital mix: a test of the life-cycle theory. Journal of Financial economics, 81(2), 227-254. https://doi.org/10.1016/j.jfineco.2005.07.005

Denis, D. J., \& Osobov, I. (2008). Why do firms pay dividends? International evidence on the determinants of dividend policy. Journal of Financial economics,89(1), 62-82. https://doi.org/10.1016/j.jfineco.2007.06.006

Dhanani, A. (2005). Corporate dividend policy: the views of British financial managers. Journal of Business Finance \& Accounting, 32(7-8), 1625-1672. https://doi.org/10.1111/j.0306-686X.2005.00643.x

D’souza, J., \& Saxena, A. K. (1999). Agency cost, market risk, investment opportunities and dividend policy-an international perspective. Managerial Finance, 25(6), 35-43. https://doi.org/10.1108/03074359910765993

Fama, E. F. \& French, K. R. (2001). Disappearing dividends: changing firm characteristics or lower propensity to pay?. Journal of Financial economics, 60(1), 3-43. https://doi.org/10.1016/S0304-405X(01)00038-1

Farsio, F., Geary, A., \& Moser, J. (2004). The relationship between dividends and earnings. Journal for Economic Educators, 4(4), 1-5.

Faulkender, M., Milbourn, T. \& Thakor, A. (2006, March). Capital structure and dividend policy: two sides of the same coin. In Seminar Participants at Washington University March (Vol. 30).

Gaver, J. J. \& Gaver, K. M. (1993). Additional evidence on the association between the investment opportunity set and corporate financing, dividend, and compensation policies. Journal of Accounting and Economics, 16(1-3), 125-160. https://doi.org/10.1016/0165-4101(93)90007-3

Gillet, R., Lapointe, M. A. \& Raimbourg, P. (2008). Dividend policy and reputation. Journal of Business Finance \& Accounting, 35(3-4), 516-540. https://doi.org/10.1111/j.1468-5957.2008.02074.x

Gitman, L. (2009). Principles of managerial finance. Pearson Higher Education .

Gordon, M. J., \& Shapiro, E. (1956). Capital equipment analysis: the required rate of profit. Management science, 3(1), 102-110. https://doi.org/10.1287/mnsc.3.1.102 
Gordon, M. J. (1959). Dividends, earnings, and stock prices. The review of economics and statistics, 99-105. https://doi.org/10.2307/1927792

Gunasekarage, A., \& Power, D. M. (2006). Anomalous evidence in dividend announcement effect. Managerial Finance, 32(3), 209-226. https://doi.org/10.1108/03074350610646726

Gupta, A., \& Banga, C. (2010). The determinants of dividend policy. Indian Institute of Management Calcutta, 37 (2), 63-77.

Habib, M. A., \& Alam, M. Z. (2011). Business analysis of pharmaceutical firms in Bangladesh: problems and prospects. Journal of Business and Technology (Dhaka), 6(1), 61-77.

Han, K. C., Lee, S. H., \& Suk, D. Y. (1999). Institutional shareholders and dividends. Journal of financial and Strategic Decisions, 12(1), 53-62.

Hardin III, W., \& Hill, M. D. (2008). REIT dividend determinants: excess dividends and capital markets. Real Estate $\quad$ Economics, 36(2), 349-369. https://doi.org/10.1111/j.1540-6229.2008.00216.x

Higgins, R. C. (1981). Sustainable growth under inflation. Financial Management, 36-40. https://doi.org/10.2307/3665217

Holder, M. E., Langrehr, F. W., \& Hexter, J. L. (1998). Dividend policy determinants: An investigation of the influences of stakeholder theory. Financial management, 73-82. https://doi.org/10.2307/3666276

Howatt, B., Zuber, R. A., Gandar, J. M., \& Lamb, R. P. (2009). Dividends, earnings volatility and information. Applied Financial Economics, 19(7), 551-562. https://doi.org/10.1080/09603100802345397

Islam, M. N., \& Mili, S. A. (2012). Financial Diagnosis of Selected Listed Pharmaceutical Companies in Bangladesh. European Journal of Business and Management, 4(4), 70-88.

Jensen, G. R., Solberg, D. P., \& Zorn, T. S. (1992). Simultaneous determination of insider ownership, debt, and dividend policies. Journal of Financial and Quantitative analysis, 27(02), 247-263. https://doi.org/10.2307/2331370

Jensen, M. C. (1986). Agency costs of free cash flow, corporate finance, and takeovers. The American economic review, 76(2), 323-329.

Juma'h, A. H., \& Pacheco, C. J. O. (2008). The financial factors influencing cash dividend policy: A sample of US manufacturing companies. Inter Metro Business Journal, 4(2), 23-43.

Kang, S., Sul, W., \& Kim, S. (2010). Impact of foreign institutional investors on dividend policy in korea: a stock market perspective.

Kania, S. L., \& Bacon, F. W. (2005). What factors motivate the corporate dividend decision? American Society of Business and Behavioral Sciences E-Journal, 1(1), 95-107.

Khan, K. I. (2012). Effect of Dividends on Stock Prices-A case of chemical and 
pharmaceutical Industry of

https://doi.org/10.5923/j.mm.20120205.02

Pakistan. Management, 2(5),

141-148.

Kohli, H. S., Sharma, A., \& Sood, A. (Eds.). (2011). Asia 2050: realizing the Asian century. SAGE Publications India.

Kumar, R., \& Kumar Jha, P. (2012). Determinants of Corporate Dividend Policy in India-A Study of Listed IT Companies at BSE.

La Porta, R., Lopez-de-Silanes, F., Shleifer, A., \& Vishny, R. W. (2000). Agency problems and dividend policies around the world. The journal of finance,55(1), 1-33. https://doi.org/10.1111/0022-1082.00199

Lintner, J. (1956). Distribution of incomes of corporations among dividends, retained earnings, and taxes. The American Economic Review, 46(2), 97-113.

Lintner, J. V. (1959). The financing of corporations.

Lintner, J. (1965). The valuation of risk assets and the selection of risky investments in stock portfolios and capital budgets. The review of economics and statistics, 47(1), 13-37. https://doi.org/10.2307/1924119

Lloyd, W. P., Jahera, J. S., \& Page, D. E. (1985). Agency costs and dividend payout ratios. Quarterly Journal of Business and Economics, 19-29. https://doi.org/10.1111/j.1540-6288.1985.tb00256.x

Majumder, T. H., \& Rahman, M. M. (2011). Financial analysis of selected pharmaceutical companies in Bangladesh. Journal of Biology, Agriculture and Healthcare, 1 (2), 25, 50.

Marfo-Yiadom, E. and Agyei, S.K., (2011). Determinants of dividend policy of banks in Ghana. International Research Journal of Finance and Economics, 61(61), 99-108.

Mehta, A. (2012). An empirical analysis of determinants of dividend policy-evidence from the UAE companies. Global Review of Accounting and Finance, 3(1), 18-31.

Miller, M. H., \& Modigliani, F. (1961). Dividend policy, growth, and the valuation of shares. the Journal of Business, 34(4), 411-433. https://doi.org/10.1086/294442

Mirza, H. H., \& Azfa, T. (2010). Ownership structure and cash flows as determinants of corporate dividend policy in Pakistan. International Business Research, 3(3).

Moradi, M., Salehi, M., \& Honarmand, S. (2010). Factors Affecting Dividend Policy: Empirical Evidence of Iran. Poslovna izvrsnost, 4(1), 45-61.

Nissim, D., \& Ziv, A. (2001). Dividend changes and future profitability. The Journal of Finance, 56(6), 2111-2133. https://doi.org/10.1111/0022-1082.00400

Nizar Al-Malkawi, H. A. (2007). Determinants of corporate dividend policy in Jordan: an application of the Tobit model. Journal of Economic and Administrative Sciences, 23(2), 44-70. https://doi.org/10.1108/10264116200700007 
Nnadi, M. A., \& AKPOMI, M. E. (2005). The effect of Taxes on dividend policy of banks in Nigeria. International Research Journal of Finance and Economics. 19, 48-55. https://doi.org/10.2139/ssrn.873828

Ohlson, J. A., \& Juettner-Nauroth, B. E. (2005). Expected EPS and EPS growth as determinantsof value. Review of accounting studies, 10(2-3), 349-365. https://doi.org/10.1007/s11142-005-1535-3

Omran, M., \& Pointon, J. (2004). Dividend policy, trading characteristics and share prices: empirical evidence from Egyptian firms. International Journal of Theoretical and Applied Finance, 7(02), 121-133. https://doi.org/10.1142/S0219024904002384

Pandey, I. M. (2003). Corporate dividend policy and behaviour: the Malaysian evidence. Asian Academy of Management Journal, 8(1), 17-32.

Papadopoulos, D. L., \& Charalambidis, D. P. (2007). Focus on present status and determinants of dividend payout policy: Athens Stock Exchange in perspective. Journal of Financial Management \& Analysis, 20(2), 24-37.

Patra, T., Poshakwale, S., \& Ow-Yong, K. (2012). Determinants of corporate dividend policy in Greece. Applied Financial Economics, 22(13), 1079-1087. https://doi.org/10.1080/09603107.2011.639734

Pruitt, S. W., \& Gitman, L. J. (1991). The interactions between the investment, financing, and dividend decisions of major US firms. Financial review, 26(3), 409-430. https://doi.org/10.1111/j.1540-6288.1991.tb00388.x

Rafique, M. (2012). Factors affecting dividend payout: Evidence from listed non-financial firms of Karachi stock exchange. Business Management Dynamics, 1(11), 76-92.

Ramachandran, A., \& Packkirisamy, V. (2010). The impact of firm size on dividend behaviour: A study with reference to corporate firms across industries in India. Managing Global Transitions, 8(1), 49.

Redding, L. S. (1997). Firm size and dividend payouts. Journal of Financial Intermediation, 6(3), 224-248. https://doi.org/10.1006/jfin.1997.0221

Rehman, A., \& Takumi, H. (2012). Determinants of dividend payout ratio: Evidence from Karachi Stock Exchange (KSE). Journal of Contemporary Issues in Business Research, 1(1), 20-27.

Rozeff, M. S. (1982). Growth, beta and agency costs as determinants of dividend payout ratios. Journal of financial 249-259. https://doi.org/10.1111/j.1475-6803.1982.tb00299.x

Saad, K. S. (2012). An overview of the pharmaceutical sector in Bangladesh. BRAC EPL Stock Brokerage Limited, Dhaka.

Saravanakumar, S. (2011). Determinants of Corporate Dividend Policy. Asia Pacific Business Review, 7(2), 25-36. https://doi.org/10.1177/097324701100700203 


\section{Macrothink}

Asian Journal of Finance \& Accounting ISSN 1946-052X 2017, Vol. 9, No. 1

Singhania, M. (2006). Taxation and corporate payout policy. Vikalpa, 31(4), 47-66.

Travlos, N., Trigeorgis, L., \& Vafeas, N. (2001). Shareholder wealth effects of dividend policy changes in an emerging stock market. Multinational Finance Journal, 5(2), 87 - 112. https://doi.org/10.17578/5-2-1

VanDuzer, T. (2003). TRIPS and the pharmaceutical industry in Bangladesh: Towards a national strategy (No. 24). Centre for Policy Dialogue (CPD).

Vogt, S. C. (1994). The cash flow/investment relationship: evidence from US manufacturing firms. Financial management, 3-20. https://doi.org/10.2307/3665735

World Bank. (2008). Public and Private Sector Approaches to Improving Pharmaceutical Quality in Bangladesh. Dhaka: World Bank. Retrieved 25 February 2013 from http://siteresources.worldbank.org/INTBANGLADESH/Resources/pharmaceutical.pdf

Zameer, H., Rasool, S., Iqbal, S., \& Arshad, U. (2013). Determinants of Dividend Policy: A case of Banking sector in Pakistan. Middle-East Journal of Scientific Research, 18(3), $410-424$. 